\title{
Quantitative and Qualitative Basis of Customer Relationship Management Concept Development in the Adriatic Ports
}

\section{Senka Šekularac-Ivošević, Sanja Bauk}

Quantitative-qualitative analyses of the marketing aspects of operation of the ports of Bar, Ploče and Rijeka as extremely competitively positioned on the common target market are considered in this paper. Therefore, market investigations have been carried out and users' preferences have been established, an overview of the conditions has been made on the basis of which the actual positions of ports have been determined and represented by perception maps, while on the basis of Markov model a forecast has been made for consumer commitment in the following three time intervals, each of them one year long. The numerical results gained, as well as comments in the marketing sense, should contribute to creating a base of knowledge about target users, so as to support the development of CRM (Customer Relationship Management) concept in the ports analysed.

\section{KEY WORDS}

$\sim$ Marketing of maritime ports

$\sim$ Quantitative-qualitative analysis

$\sim$ Markov model

$\sim$ CRM concept

University of Montenegro, Faculty of Maritime Studies, Dobrota 36, 85330 Kotor, Montenegro

e-mail: senkas@ac.me, bsanjaster@gmail.com

\section{INTRODUCTION}

Assessment of market potential and predicting future conditions of a certain business system represents one of the basic tasks in market research. For maritime ports investigating goods flows in the logistic chain and economic forces of the hinterland is highly significant, as it provides information on the size of the market, i.e. individual market segments.

In forecasting a future position (market participation rate) of a port on the market, from a general aspect, qualitative, quantitative and combined qualitative-quantitative methods are applied.

Qualitative or the so-called non-quantitative methods primarily rely on the psychological characteristics of the respondents such as opinions, attitudes, values, expectations, feelings, perceptions and alike. Experts, most commonly from the management structure, on the basis of their own assessment supported by the experienced acquired, forecast the future development of a port. From this group of methods (Bush et al., 1998), the following methods are singled out: assessment method (Delphi method) and counting method (inspecting users' purchase intentions, test marketing, etc). The application of qualitative methods is most effective when they are used for short-term forecasts, in cases when there are no available data from the past, in shortage of time and capacities for the application of quantitative methods, i.e. when they are used as a basis for the application of the others (Hess, 2004).

Quantitative methods, according to Kotler, are included in the third forecasting method, i.e. the method of what people have done. Namely, already in the early 1990s Kotler made a 
division into marketing forecasting methods such as (Ivanković, 2000): what people say (investigating buyers' intentions, sellers' opinions, experts' opinions), what people do (testing products on the market), and what people have done (mathematical and statistical analysis based on the report about past sale - analysis of traditional time series and statistical analysis of demand). These kinds of analyses are based on numerous deterministic and stochastic methods (Bauk, 2010; Bauk, 2011; Hess, 2004). The basis for their application are data on the movement of a phenomenon and influencing factors from the past, while the support is represented by an intensive development of computers and programmes that effectively include into calculation a large number of data and generate optimum solutions.

Combining qualitative-quantitative methods represents a kind of fusion of theoretical explanations of state and movement on the market, here in the marketing sense of the term, and of well-known and structured quantitative methods.

\section{BASICS OF CRM CONCEPT OF MODERN PORTS}

The effectiveness of the entire operation of maritime ports depends to a high degree on qualitative marketing decisions. In an environment in which ports operate a there is a continuously increasing risk that makes appropriate business decision-making complex. Therefore, it is necessary for every port to have at disposal reliable information gained by the process of market research.

The process of market research takes place in seven consecutive steps: definition of the problem and aims of the research, determination of sources of information, development of sampling strategy, determination of methods and techniques of data collection, collection of data, their processing and analysis, and reporting the results to decision-makers (Hanić, 2003). By the process of market research the necessary information on the subjects on the market are provided, primarily on users, on the programme of marketing fusion, on marketing politics and strategies, etc.

When loyalty of port users is analysed, it is important to take into consideration the degree of user satisfaction, i.e. whether user expectations have been exceeded, whether the user is planning to continue business cooperation, and how ready he is to pay for the services, and alike. It is often the case that the user gives up at the moment when a better possibility occurs with competition. This means that although a port has a lower rate, low-quality service de-motivates the user to continue business cooperation. A small number of users are ready to submit appeals for services, which decreases the possibility of discovering reasons of user giving up using port services. Therefore, in this business it is very important to have knowledge about users, and this is best achieved if feedback information on user satisfaction is available. For this purpose, the management and employees should develop a system of port user complaint management (Lovelock et al., 2004), so that a new service of transhipment, stowage, or added value can improve user satisfaction.

Although modern technologies have changed business conditions on the maritime market, among shipping companies traditionalism is still cherished, and respectability, a positive image that a port has is appreciated. Until recently in the literature considering user satisfaction and loyalty, but also in practice, the marketing was focused on attracting new users in such a way as to offer flexible prices, special offers and very aggressive promotion (Berry, 1995). However, nowadays at the level of strategic management efforts are made in user retention, concentration on achieving higher rates with users than market participation, establishment and maintenance of long-term relationships with users and collecting as much information about them as possible as input for top-quality marketing decision-making (Đukić, 2000). By taking the central position in a port system, a service user has practically determined the direction of the management towards meeting hisown requirements, as well as towards building up and fostering their mutual relationships.

Modern ports in their operation recognise and accept techniques and knowledge from the area of relationship marketing (RM - Relationship Marketing) and customer relationship management (CRM - Customer Relationship Management). In the very definition of marketing the emphasis is on relationship marketing as marketing represents an organisational function and a set of processes for creating, communication and delivery of values to the user, as well as management of relationships with users so as to achieve benefit for the organisation and its stakeholders (Harker et al., 2006). Marketing of port-users relationship is focused on the value that is delivered, not on the port service attributes. Its end result are not unidirectional transactions between users and the port, but creating common assets of customers, the so-called network marketing that basically has a database on the existing and potential users (Gligorijević, 2007).

\section{INVESTIGATION OF USER PREFERENCES AND DETERMINATION OF ACTUAL POSITION OF PORTS ON THE MARKET}

For port management nowadays there are numerous marketing challenges, among which the market research process management is primary. This process includes collecting information on the existing and potential users, economic, technological, social and political development, changes in trade and logistics, regulatory frame and its implications for port management, development of competitive ports and other stakeholders, etc. All the investigations mentioned above aim at solving the dilemma: why is a certain port preferred to its alternatives? 
Modern marketing aspects of port operation include finding effective ways of strengthening the positions on the market, developing strategies of retention and increase of market participation, market segmentation and selection of target markets (segments), differentiating offer and positioning. Besides, marketing as a concept of maritime port operation but also practice, offers solutions for measuring buyer satisfaction, and especially for strategic attraction and retention of loyal clients who are profitable. Also, it is necessary to more intensively apply the spectrum of all marketing strategies in the domain of port operation, but also a wider overview of the significance of port service offer instruments (7P-service product, tariffs, distribution channels, integrated marketing communications, service processes, physical evidence, people). Marketing approach to port management is based on knowledge about user needs, where the focus moves from the internal performances of port operation, what the capacity is, towards market, what user preferences are.

Generally, positioning of ports analysed in this paper should enable clear determination of place in the minds of the users, which is determined in the way in which users see the offer of an actual port in comparison with a competitive one (Gligorijević, 2009). The position that is being built up is actually a place that organisations (ports) are trying to take in the mental map of users (Gligorijević, 2011).

\subsection{Methodology}

In this paper two sets of criteria are analysed: quantitative (7) and qualitative (26) that are shown in Tables 1 and 2. These two sets of criteria are further divided into several sub-sets (Bauk 2010; Pardali et al., 2008; Šekularac-Ivošević et al., 2012). Namely, to the Adriatic container ports mentioned above (Bar, Ploče and Rijeka) the following methodology has been applied with the aim of their appropriate positioning:

- $\quad$ First, quantitative and qualitative criteria are identified;

- Then, a focus group is formed consisting of experts, researchers and users who are asked to assess the importance of each criterion, each of them according to his/her own feeling, with a numerical value on a scale from 1 to 10 ;

- After the marks of all the testees have been collected, their mean values are determined by all parameters, for each of the ports analysed;

- These mean values are later used as weight coefficients that are pondered, i.e. multiplied by the original values of the criteria discussed;

- Individual results gained by multiplying the original value of each criterion with the appropriate weight coefficient are then summed up for each of the three ports analysed;

- Finally, the results gained for quantitative and qualitative criteria, as well as their sum, have been used for positioning of the ports investigated and their representation by appropriate perception maps.

Mathematical formulation of the methodology described above is given below.

In the first step each of the criteria analysed has been assigned an appropriate variable: $v_{A i}$-for quantitative criteria $(i=\overline{1,7})$, and $v_{B j}$ - for qualitative criteria $(j=\overline{1,26})$. Values of the variables $v_{A i}$ are, in fact, exact numerical values that correspond to the quantitative criteria for each of the three ports analysed (Table 1). The values of the variables $v_{B j}$ are binary $(0,1)$ values

Table 1. Quantitative criteria (A).

\begin{tabular}{|c|c|c|c|c|c|c|}
\hline \multirow{9}{*}{ 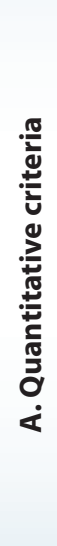 } & \multirow{2}{*}{ Features } & \multirow{2}{*}{\multicolumn{2}{|c|}{ Sub-features }} & \multicolumn{3}{|c|}{ Ports } \\
\hline & & & & Bar & Ploče & Rijeka \\
\hline & \multirow{5}{*}{$\begin{array}{c}\text { A1. Features of } \\
\text { container terminal }\end{array}$} & A1.1 & Number of berths (number) & 2.00 & 1.00 & 2.00 \\
\hline & & A1.2 & Entire length of the berth (m) & 330.00 & 280.00 & 450.00 \\
\hline & & A1.3 & Maximum depth of the local sea area $(\mathrm{m})$ & 14.00 & 13.80 & 12.00 \\
\hline & & A1.4 & Container terminal capacity at a moment (TEU) & 1760.00 & 1400.00 & 6500.00 \\
\hline & & A1.5 & Number of gantry cranes (No.) & 1.00 & 1.00 & 3.00 \\
\hline & \multirow{2}{*}{$\begin{array}{l}\text { A2. Total cargo } \\
\text { throughput and human } \\
\text { potentials }\end{array}$} & A2.1 & Total cargo throughput (t) & 2407.40 & 4532.80 & 4611.70 \\
\hline & & $A 2.2$ & Daily operations (hours) & 24.00 & 24.00 & 24.00 \\
\hline
\end{tabular}


(Table 2). Thus, if the port analysed has a certain qualitative characteristic (criterion), then the variable $v_{B j}$ will have value one (1), and the opposite, if the port analysed does not have a certain qualitative characteristic, the value of the relative variable will be zero (0) (Pardali et al., 2008).

The values of the variables according to all singularly taken quantitative criteria are here divided with the maximum value among them, in case of each port discussed, in order to mitigate the differences in individual numerical values. Therefore, the variables: $v_{A i}(i=\overline{1,7})$, are replaced by new variables:
$\overline{v_{A_{i}}}=v_{A_{i}} / \operatorname{MAX}\left(\left\{v_{A_{i}}, i=\overline{1,7}\right\}\right)$.

The intention is, in fact, that all the values of quantitative criteria are reduced to the interval from 0 to $1\left(0 \leq \overline{v_{A_{t}}} \leq 1\right)$. Furthermore, the respondents forming the focus group: experts (5), researchers (5) and users (10), have assessed the importance of each of the criteria mentioned above with marks from 1 to 10. Then, mean values of their marks have been determined according to all the parameters analysed, for each of the three ports observed. These values have served, then, as weight

Table 2. Quantitative criteria (B).

\begin{tabular}{|c|c|c|c|c|c|c|}
\hline \multirow{2}{*}{\multicolumn{2}{|c|}{ Features }} & \multirow{2}{*}{\multicolumn{2}{|c|}{ Sub-features }} & \multicolumn{3}{|c|}{ Ports } \\
\hline & & & & Bar & Ploče & Rijeka \\
\hline \multirow{26}{*}{ 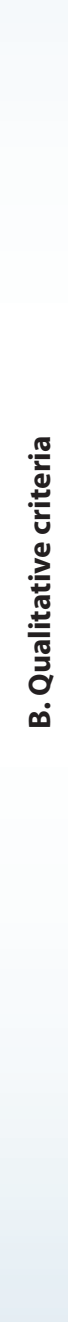 } & \multirow{5}{*}{$\begin{array}{l}\text { B1. Infra- and super- } \\
\text { structural features }\end{array}$} & B1.1 & General cargo terminal & 1 & 1 & 1 \\
\hline & & B1.2 & Dry bulk cargo terminal & 1 & 1 & 1 \\
\hline & & B1.3 & Liquid cargo terminal & 1 & 1 & 1 \\
\hline & & B1.4 & Ro-Ro terminal & 1 & 1 & 1 \\
\hline & & B1.5 & Passenger terminal & 1 & 1 & 1 \\
\hline & \multirow{5}{*}{$\begin{array}{l}\text { B2. Connections with } \\
\text { hinterland }\end{array}$} & B2.1 & Railroad connection & 1 & 1 & 1 \\
\hline & & B2.2 & Road connection & 1 & 1 & 1 \\
\hline & & B2.3 & Pipelines connections & 0 & 0 & 1 \\
\hline & & B2.4 & Barge service & 0 & 0 & 0 \\
\hline & & B2.5 & Shuttle service & 0 & 0 & 0 \\
\hline & \multirow{5}{*}{ B3. Marketing features } & B3.1 & Free zone & 1 & 1 & 1 \\
\hline & & B3.2 & Added value logistic services & 1 & 0 & 1 \\
\hline & & B3.3 & Distribution centres & 1 & 0 & 1 \\
\hline & & B3.4 & Quality management system & 1 & 0 & 1 \\
\hline & & B3.5 & Integrated marketing communications & 0 & 0 & 0 \\
\hline & \multirow{4}{*}{$\begin{array}{l}\text { B4. Management } \\
\text { models in ports }\end{array}$} & B4.1 & Service port model & 0 & 0 & 0 \\
\hline & & B4.2 & Tool port model & 0 & 0 & 0 \\
\hline & & B4.3 & Landlord port model & 1 & 1 & 1 \\
\hline & & B4.4 & Private port model & 0 & 0 & 0 \\
\hline & \multirow{5}{*}{$\begin{array}{l}\text { B5. Services to ship and } \\
\text { cargo }\end{array}$} & B5.1 & Ship monitoring & 1 & 0 & 1 \\
\hline & & B5.2 & Ship repair & 0 & 0 & 1 \\
\hline & & B5.3 & Ship chandler & 1 & 0 & 1 \\
\hline & & B5.4 & Container control & 1 & 1 & 1 \\
\hline & & B5.5 & Container leasing & 0 & 0 & 0 \\
\hline & \multirow{2}{*}{ B6. ICT applications } & B6.1 & EDI service & 1 & 1 & 1 \\
\hline & & B6.2 & VTS service & 0 & 0 & 0 \\
\hline
\end{tabular}


coefficients: $w_{A i}$ - for quantitative criteria $(i=\overline{1,7})$, and $w_{B j}$ - for qualitative criteria $(j=\overline{1,26})$. Finally, the results summed up for quantitative and qualitative criteria are determined according to the following simple, mathematical formulae (1) and (2), for each individual port:

$$
\begin{aligned}
& S A_{k}=\sum_{i=1}^{7} W_{A_{i}} \cdot \overline{V_{A_{i}}}, k=\overline{1,3} \\
& S B_{k}=\sum_{j=1}^{26} W_{B_{j}} \cdot v_{B_{j}}, k=\overline{1,3}
\end{aligned}
$$

where,

$S A_{k}$ - the total result for quantitative criteria for k port

$S B_{k}$ - the total result for qualitative criteria for k port;

$W_{A i}$ - weight coefficient for i quantitative criterion from the set A criteria;

$\overline{v_{A i}}$ - variable whose value is gained by dividing (original) value of the i criterion from the set $A$, with the maximum numerical value of that criterion for each of the ports analysed;

$w_{B j}$ - weight coefficient for $\mathrm{j}$ qualitative criterion from the set $\mathrm{B}$ criteria;

$v_{B j}$ - binary value of $\mathrm{j}$ qualitative criterion;

$k \quad$ - number of ports analysed, i.e. $k=3$.

For calculation of (1) and (2) two embedded Excel functions of SUMPRODUCT type (array_1; \$array_2) were used: one for the quantitative criteria (i.e. for the set $\mathrm{A}$ ) and the other for qualitative criteria (i.e. for the set B). In both cases «array_1» corresponds to the variable values of the criteria, while «\$array_2» corresponds to the fixed values of weight coefficients.

\subsection{Numerical results}

On the basis of calculations (1) and (2), perception maps for quantitative and qualitative analyses of the ports discussed were created, aiming at their mutual positioning and doing appropriate analyses on the market of port services. For this purpose matrices of weight coefficients were used, gained through interviews, and included below:

a) for quantitative criteria

$$
W_{A i}=\left[\begin{array}{llllll}
A 1: & 7.88 & 8.17 & 8.61 & 8.83 & 8.28 \\
A 2: & 8.04 & 8.11 & & &
\end{array}\right] ;
$$

and

b) for qualitative criteria

$$
W_{B j}=\left[\begin{array}{llllll}
B 1: & 7.95 & 7.73 & 7.15 & 7.83 & 7.36 \\
B 2: & 9.41 & 9.22 & 8.22 & 7.68 & 7.23 \\
B 3: & 7.88 & 7.89 & 8.34 & 8.31 & 8.34 \\
B 4: & 7.04 & 6.73 & 7.43 & 7.61 & \\
B 5: & 8.14 & 8.20 & 8.36 & 8.86 & 8.11 \\
B 6: & 8.51 & 8.41 & & &
\end{array}\right] .
$$

It should be emphasized that determining weight coefficients through interviews requires from the respondents to be expert, and to have a highly developed ability of logical reasoning, so that the assessment of even only one highly qualified expert (or, 20 professionals and long-time users, such as the case with this paper) is more significant than the assessment of a far larger number of less expert and experienced persons in this area (Sivilevičius et al., 2010). Using formulae (1) and (2), values of weight coefficients $w_{A i}$ and $w_{B j}$, as well as Excel embedded function SUMPRODUCT (Šekularac-Ivošević et al., 2012), in the manner described in detail in the previous paragraph, perception maps represented in Figures 1 and 2 have been created.

First, two sub-sets of quantitative criteria are analysed: one that refers to the container terminal infrastructure and the other related to cargo handling and human resources in ports. On the basis of data that were gained through market research, we come to a conclusion that according to the first set of criteria the best positioned port is Rijeka, followed by the ports of Bar and Ploče. This is understandable with regard to their real infra and suprastructural equippedness, as well as economic development of the hinterland. According to the other analysed quantitative subset of criteria, the positions of ports are equal, in that the port of Ploče has a somewhat better position in relation to the port

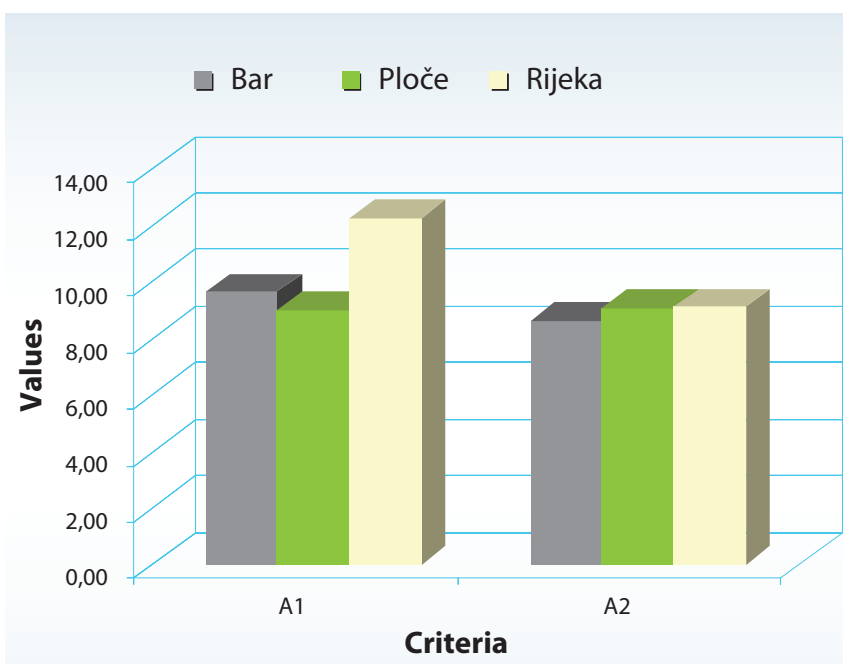

Figure 1. Positions of ports determined on the basis of quantitative criteria (A). 


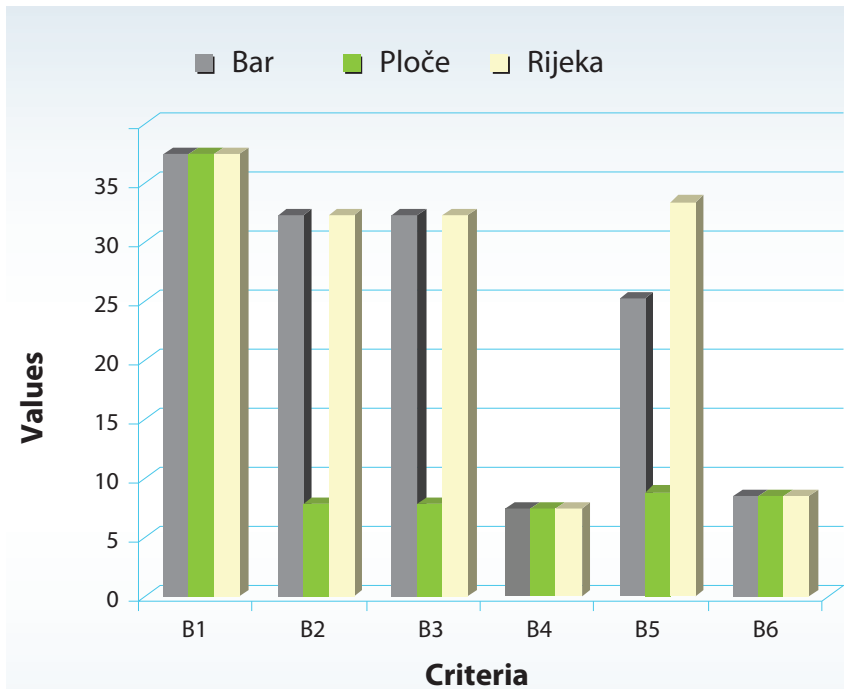

Figure 2. Positions of ports determined on the basis of qualitative criteria (B).

of Bar, which results from a higher transhipment capacity of this port at a yearly level (Figure 1).

On the basis of actual positions of the ports considered (Figure 2), gained by previously done analyses of qualitative criteria, the following conclusion is reached:

- Ports of Bar, Ploče and Rijeka have equal positions regarding infra and supra- structural characteristics. This is collision with the results of the previously done quantitative analysis, as numerical analysis of qualitative criteria is pretty rough here, or random. Namely, here the question is raised if a port has (1), or does not have (0) a certain characteristic, but calculations are not done with any definite indicator, if subjective weight coefficients determined by the testees are excluded;

- When connections with the hinterland are considered, the ports of Rijeka and Bar, according to the results gained here, have fairly equal positions, while the port of Ploče, has in this sense a significantly worse position. However, here remains, similarly as in the previous case, an open question of the quality of connections with the hinterland and of economic power (development) of the hinterland;

- As regards marketing characteristics, the results gained point to equal positions of the ports of Rijeka and Bar, where the port of Ploče lags behind since it does not offer added value services, it does not have distribution centres, an established quality system (QMS) and integrated marketing communications;

- As regards the model of port management, the positions of the ports considered here are equal for the simple reason that they are all of the same landlord port model;
- As regards the range of services offered to ship and cargo, the port of Rijeka has advantage, the port of Bar is second, while the port of Ploče is at the lowest position because of all the services of the type it offers only the services of following the containers at the terminal;

Finally, when ICT solutions are considered, all three ports are included in EDI system of document distribution so that in this regard they have equal positions. Regarding the introduction of VTSMIS, presently a lot is being done with IPA funds in the port of Bar (Project: „Vessel Traffic Management Information System (VTMIS) and response to marine pollution incidents", CRIS Number: 2011/023-173, 2011).

\section{FORMING A MODEL OF FORECASTING USER COMMITMENT IN A FUTURE PERIOD}

In marketing the Markov processes are used as a support to management, and most often for research and forecasting consumer behaviour regarding their loyalty. The demand for port services is a process that is distinguished by the basic Markov characteristic, i.e. the characteristic that the present state contains all the relevant information on the past and future states of port business systems (Mennis et al., 2008). In the investigations carried out so far the Markov stochastic processes have been considered in the sense of modelling mass servicing systems in maritime transport, as well as the application of the Markov theory to increase effectiveness of port operations (Mennis et al., 2008; Hess et al., 2009; Hess et al., 2011). Almost the majority of these works considers the technical-technological components of the port system, while special attention in this paper is paid to the prediction of future states of demand, based on homogeneous historical information on users who remained committed to the port, those who have appeared as new, as well as those who for some reasons stopped using the services of the ports investigated.

On the example of application of the Markov model in the assessment of the future positions of the ports regular shipping lines and cargo owners are analysed as target users on container terminals of the ports of Bar, Ploče and Rijeka. This is done for the reason that it is very complicated to gather information on the total number of users at the level of the port, because very few of them possess the majority of prerequisites for the development of CRM concept, i.e. they primarily do not possess systematized information on users in the way that the modern marketing information system requires.

\subsection{Methodology}

On the basis of previously determined positions of ports, as well as information collected by surveying and interviewing experts on approximate number of users on container terminals, 
the following procedure of calculating predictable market participation of the ports mentioned above is proposed (Backović et al., 2004):

(1) Observation of demand for port services on container terminals and recording changes in the number of users, which implies:

- State at the beginning of the first time unit, i.e. the number of users of each port at the moment $t_{i}$;

- State at the beginning of the second time unit, i.e. the number of users of each port at the moment $\mathrm{t}_{\mathrm{i}+1^{\prime}}$

- Movement of changes, transition of users from one to a second and third port and vice versa, in the period observed $\mathrm{t}_{\mathrm{i}}-\mathrm{t}_{\mathrm{i}+1}$;

(2) Calculation of the initial vector of state $S_{0}$;

(3) Forming of square Markov matrix of transitional probabilities $M$ based on the data from 1), where the condition that the sum of transitional probabilities in the matrix rows always equals 1 has to be satisfied;

(4) Analysing the evolution of the market at the end of the three-year-long period through determination of new vectors of states $\mathrm{S}_{1}, \mathrm{~S}_{2^{\prime}} \mathrm{S}_{3^{\prime}}$, where the sum of state vector elements always has to be 1 (Backović et al., 2001); and

(5) Graphic representation of the positions of ports in the period considered.

On the basis of the results of surveying data were gained that are systematised in Table 3. For the period from 2009 to 2011 the container terminal of the port of Rijeka has the highest total number of users. The container terminal of the port of Bar has more users than the terminal of the port of Ploče in the time intervals observed. These data are in line with the volume of transhipment on the container terminals of these ports, i.e. they completely match the positions on the perception maps that are shown in the process of their positioning.

In order to form a Markov matrix of transitional probabilities it is necessary to analyse the structure of user inflow and outflow,

Table 3. State of demand for port services in the period 2009-2011.

\begin{tabular}{ccccc}
\hline \multirow{2}{*}{ State/Ports } & \multicolumn{3}{c}{ Ports } & Total: \\
\cline { 2 - 4 } & Bar & Ploče & Rijeka & \\
\hline State in ti & 8 & 5 & 17 & 30 \\
\hline User outflow & 2 & 2 & 0 & 4 \\
\hline $\begin{array}{c}\text { Remained } \\
\text { committed }\end{array}$ & 6 & 3 & 17 & 26 \\
\hline User inflow & 0 & 1 & 3 & 4 \\
\hline State in ti+1 & 6 & 4 & 20 & 30 \\
\hline
\end{tabular}

as shown in Table 4.

According to the previously presented data, from the container terminal of the port of Bar there is a noticeable outflow of one user to the port of Rijeka and another one to the port of Ploče, while the port of Rijeka did not show any user outflow towards the other two ports. The port of Ploče had in the outflow structure 2 users who transited to the port of Rijeka. On the basis of data presented in the Tables 3 and 4, using the Markov concept, a model of forecasting consumer commitment in the sense of using the services of the ports analysed has been realised.

Table 4. Structure of user inflow and outflow in the period 2009-2011

\begin{tabular}{ccccc}
\hline Inflow/Outflow & Bar & Ploče & Rijeka & Total: \\
\hline Bar & - & 1 & 1 & 2 \\
\hline Ploče & 0 & - & 2 & 2 \\
\hline Rijeka & 0 & 0 & - & 0 \\
\hline Total: & 0 & 1 & 3 & - \\
\hline
\end{tabular}

\subsection{Numerical results}

On the basis of the data collected and the previously described Markov model of the prediction of future states, the following solution has thus been reached:

a) The initial vector of state, i.e.:

$S_{0}=\left[\begin{array}{lll}\frac{6}{30} & \frac{20}{30} & \frac{4}{30}\end{array}\right]$

b) The Markov matrix of transitional probabilities:

$M=\left[\begin{array}{ccc}\frac{6}{8} & \frac{1}{8} & \frac{1}{8} \\ \frac{0}{17} & \frac{17}{17} & \frac{0}{17} \\ \frac{0}{5} & \frac{2}{5} & \frac{3}{5}\end{array}\right] ;$

c) At the end of the first year, i.e. for $t=1$ it follows that: $S_{1}=S_{0} \cdot M=\left[\begin{array}{lll}0.150 & 0.745 & 0.105\end{array}\right]$;

d) At the end of the second year, i.e. for $t=2$ it follows that: $S_{2}=S_{1} \cdot M=\left[\begin{array}{lll}0.1125 & 0.80575 & 0.08175\end{array}\right]$;

e) At the end of the third year, i.e. for $\mathrm{t}=3$ it follows that: $S_{3}=S_{2} \cdot M=\left[\begin{array}{lll}0.084375 & 0.852512 & 0.063113\end{array}\right]$;

f) Graphic representation of port positions in the period considered is given in Figure 3. 
The tendency that can be noted from Figure 3 goes in two divergent directions. It can be expected that the ports of Bar and Ploče in the forthcoming three-year-long period (2012-2014) will record, each of them, a mild decrease in the demand for services. On the other hand, a balanced increase in the demand will be characteristic of the port of Rijeka. In the marketing sense this can mean that all the ports considered possess a definite, constant number of users, and that the management of the ports of Bar and Ploče should be more focused on improving relationships with the users, while in the case of the port of Rijeka an increase in the number of new users can realistically be expected.

\section{CONCLUSION}

The ports of Bar, Ploče and Rijeka are complex business systems whose actual moment in the development is determined by numerous processes of organisational, proprietary, staff, technical-technological reforms. In this paper, the basic idea has been to offer a solution that can be helpful to port management in view of creating high-quality CRM concept on the basis of information on users. The starting point was the determination of basic steps of the positioning strategy, which resulted in creating overview perception maps. They picturesquely, regarding each quantitative and qualitative parameter of port operation, leave space for marketing interpretation. The development of the concept of long-term management of relationships to consumers is based on certain prerequisites such as: support and active participation of the port top management; availability of staff forming the project team for the introduction of this concept; technical-technological conditions; essential financial means, etc. However, this paper goes a step further in the sense that by using the Markov model, a prediction of service user commitment for these ports within the future three-year-long period has been made. What in future should be done to continue with the practice

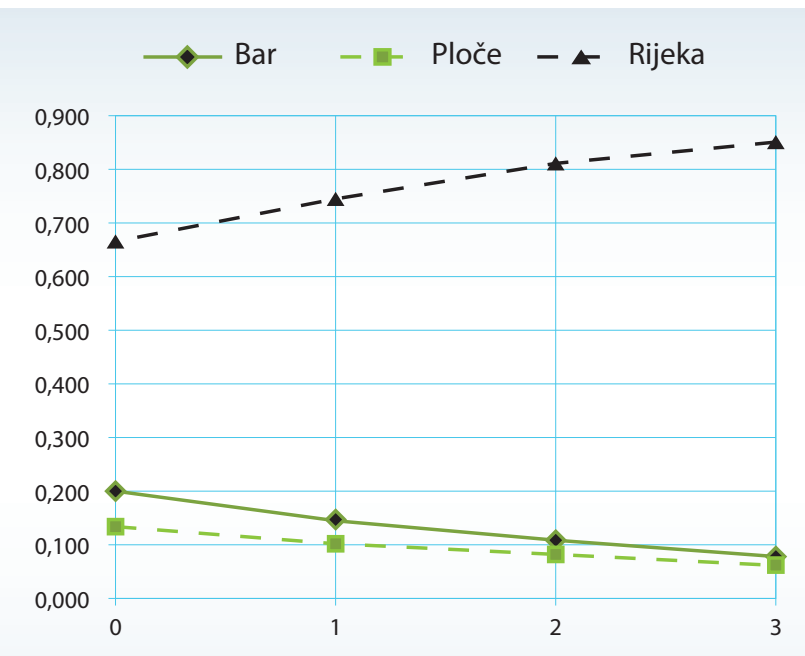

Figure 3. Forecast positions of the ports analysed on the target market. proposed in this paper is to ensure as extensive precise numerical information on port qualitative performances as possible, as well as sensitive respondents estimation with a high degree of logical reasoning and expert knowledge.

\section{REFERENCES}

Backović, M., Vuleta J., (2001), Operaciona istraživanja, Podgorica: Ekonomski fakultet.

Backović, M., Vuleta, J., Popović, Z., Prica, I., (2004), Ekonomsko matematički metodi i modeli - zbirka rešenih problema, šesto izdanje, Beograd: CID Ekonomskog fakulteta.

Bauk, S., (2010), Metode optimizacije u menadžmentu, Podgorica: Univerzitet Crne Gore.

Bauk, S., (2010), Passenger Ports Benchmarking Due to the E-Services They Offer, Montenegrin Journal of Economics, 6(11), pp. 49-56.

Bauk, S., (2011), Kvantitativne metode optimizacije u funkciji naučnog menadžmenta, Podgorica : ELIT.

Berry, L. L., (1995), Relationship marketing of services - growing interest, emerging perspectives, Journal of the Academy of Marketing Science, 23(4), pp. 236-245. http://dx.doi.org/10.1177/009207039502300402

Bush, A. J., Hair, J. F., Anderson, R. E., (1998), Profesionalni menadžment prodaje, Beograd: Grmeč.

Đukić, S., (2000), Novi pristupi u generisanju i održavanju lojalnosti potrošača, In Zbornik radova 15-tog naučnog savjetovanja Efikasnost transformacije preduzeća, Niš , Serbia, December 20, Ekonomski fakultet - Institut za ekonomska istraživanja, pp. 95-102.

Gligorijević, M., (2007), Poslovni marketing, Beograd: Centar za izdavačku delatnost Ekonomskog fakulteta.

Gligorijević, M., (2009), Poslovni marketing, Beograd: Centar za izdavačku delatnost Ekonomskog fakulteta.

Gligorijević, M., (2011), Pozicioniranje brendova na poslovnom tržištu, Beograd: Dosije studio.

Hanić, H., (2003), Istraživanje tržišta i marketing informacioni sistem, Beograd: Ekonomski fakultet.

Harker, M., Egan, J., (2006), The Past, the Present and the Future of Relationship marketing, Journal of Marketing Management, 22(1-2), pp. 215-242., http://dx.doi. org/10.1362/026725706776022326

Hess, M., Hess, S., (2011), Assignment of Stochastic Models for the Domain of Port Terminal Operations, Transport, 26(2), pp. 149-157., http://dx.doi.org/10.3846/1648 4142.2011.586017

Hess, S., (2004), Stohastički modeli u upravljanju lučkim sustavom, doktorska disertacija, Rijeka: Pomorski fakultet.

Hess, S., Hess, M., Tomas, V., (2009), A way of modelling the port operations, Pomorstvo, 23(1), pp. 137-154

Ivanković, R., (2000), Osnove marketinga, Trebinje: Fakultet za proizvodnju menadžment.

Lovelock, C., Wirtz, J., (2004), Service Marketing - People, Tehnology, Strategy, 5th Edition, New Jersey: Prentice Hall.

Mennis, E., Platis A., Lagoudis, I. N., Nikitakos, N., (2008), Improving port container terminal efficiency with the use of Markov theory, Maritime Economics and Logistics, 10(3), pp. 243-257., http://dx.doi.org/10.1057/mel.2008.3

Pardali, A., Michalopoulos, V., (2008), Determing the position of container handling ports, using the benchmarking analysis: the case of the Port of Piraeus, Maritime Policy \& Management, 35(3), pp. 271-284.

Previšić, J., Ozretić-Došen, Đ., (2004), Marketing, Zagreb: Adverta.

Sivilevičius, H., Maskeliunaite, L., (2010), The criteria for identifying the quality of passengers' transportation by railway and their ranking using AHP method, Transport, 25(4), pp. 368-381., http://dx.doi.org/10.3846/transport.2010.46

Šekularac-Ivošević, S., Bauk, S., (2012), Creating the Container Seaports Positioning Strategy Based on Benchmarking Analysis, Proc. of the 9th International Conference on Logistics and Sustainable Transport, Celje, Slovenia, June 14-16, Faculty of Logistics, (CD issue). 